\title{
Integrated Coastal and Small Island Development Plant-livestock Based in Kolaka Regency :Paper
}

\author{
LAODE MUH. MUNADI \\ Postgraduate Agricultural Sciences, Halu Oleo University \\ Kendari, South East Sulawesi \\ lmmunadi@gmail.com

\section{CHAPTER I} \\ INTRODUCTION
}

Livestock area is an area specifically intended for livestock activities or integrated as a component of farming (based on food crops, plantations, horticulture, or fisheries) and integrated as an ecosystem component. The development of farm areas should pay attention to the optimization of local resources and regional development policy strategies. Basically sustainable agriculture development is the implementation of the concept of sustainable development that aims to increase the income and welfare of the farming community at large.

The natural wealth and biodiversity of these small islands become the basic capital in the development of the nation. Small islands not only have strategic value for national economic development and improving people's welfare, but are also vulnerable to environmental damage which is one of the factors caused by mismanagement and unwise regardless of environmental support.

Coastal areas and small islands are new development areas that have enormous potential for improving the welfare of communities, especially coastal communities. This area in addition to having conservation functions, also has other functions are very important for the provision of marine goods and services. This great potential needs to be managed with an integrated approach between sectors so that the whole function can be utilized properly and sustainably. In addition to land limitations as a source of feed, the development of beef cattle is also faced with the quality of feed. So the issue of increasingly sharp land use competition will be a serious problem, the fact shows that, competition in land use has an unfavorable impact on the livestock sub-sector. Farm areas are not infrequently forced to be sacrificed because of the demand for land for the development of certain sectors such as industry and settlements, which have a greater chance of obtaining short-term profits.

For the development of beef cattle business in an area various information about the potential of the region needs to be reviewed and analyzed so that it can be known exactly the conditions of existing farms at this time (existing conditions), as well as formulate a better strategy for the development of beef cattle in the future. Based on the above, the author is interested in taking the title of the paper entitled "Development of Coastal Areas and Small Islands In An Integrated Based On Livestock-Crops in Kolaka Regency" 


\section{CHAPTER II LITERATURE REVIEW}

\subsection{The Potential of Small Islands in Indonesia}

Global warming and climate change have become the world's unrest, as their effects have threatened all of humanity and biodiversity in the world, without exception. This happens as a result of the development of the world economy which is very exploitative without taking into account the degradation of natural resources and the environment, deforestation and forest degradation. Indonesia as an Island Nation that is very vulnerable to global climate change has set a commitment to reduce emissions gases (GHG) by $26 \%$ with its own capabilities, and will be increased to $41 \%$ with other assistance, from business as usual (BAU) in 2020 even increased to $29 \%$ with its own capabilities by 2030 . The reduction of GHG in the concept of green economy should be implemented in all sectors of development.

Socioeconomic conditions of people with local wisdom, including the rights of indigenous peoples are very diverse according to specific environmental conditions, biodiversity and human relations with the environment form a very specific and unique ecosystem of small islands. This condition is not considered in designing the concept of development (Amanah, 2004). Development that has been taking place so far is very sectoral, especially the agricultural sector in a broad sense, land conversion and specific ecosystems occur massively for the agricultural sector, livestock, fisheries, settlements, infrastructure, mining followed by destructive forest management (Fadlina et al., 2013; Sari \&Muslimah, 2014; Waluyo, 2014). Such conditions will face threats with very dangerous climate change challenges (Fajri Chikmawati, 2019).

One alternative in the management and utilization of small island resources in order to obtain economic value while pursuing the conservation of natural resources is the development of ecotourism (Koroy, 2017; Fyka et al., 2018). Ecotourism offers a tourism concept that utilizes the services of natural resources and the environment, and is managed with the aim of minimizing the impact on the environment (Marasabessy et al., 2018). Providing education and contribution to efforts to protect and improve welfare for local communities (Ridlo et al., 2017).

\subsection{Coastal Potential in Indonesia}

Indonesia's territorial waters have great potential, especially biological resources, if the management of these resources is not managed into sustainable resources, then this potential will be reduced and will be a problem in the future (Fajri Chikmawati, 2019; Sambah et al., 2019). Therefore coastal and marine biological resources must be sustainable resources (Latupapua, 2007).

Coastal is a meeting area between land and sea to land covering parts of the land, both dry and submerged water (Fahriansyah \&Yoswaty, 2012). Marine properties such as tides, sea breezes, and saltwater permeations (Adam et al., 2012). The sea includes parts of the sea that are still affected by natural processes that occur on land such as sedimentation and freshwater flow, as well as caused by human activities on land such as deforestation and pollution (Sihasale, 2013; Salim \&Purbani, 2015;Djamhur et al., 2016).

\subsubsection{Ecotourism Potential}

The development of marine and fisheries to date is still far from expectations (Lasabuda, 2013). Whereas coastal areas and small islands and oceans of the Indonesian archipelago are stored the potential of natural resources and environmental services 
are very large and have not been optimally utilized (Elysia, 2014; Koroy et al., 2017). Community empowerment in the management of coastal areas and small islands gives direction for coastal communities in developing and managing coastal areas in accordance with the local wisdom of local communities (Ari Atu Dewi, 2018). The right community-based coastal management model in realizing the welfare of coastal communities has not been well formulated (Safitri et al., 2016). The ideal model of community-based coastal area management is carried out by the existence of synergy and proper interaction between the government, the community and the value of local wisdom (Haerani et al., 2012).

The empowerment of coastal communities in building a model of coastal management is also very important with the intention to encourage their independence (Yulisa et al., 2016). The use has advantages because the active participation of coastal communities can increase income, maintain the sustainability of the coastal environment, and provide flexibility for coastal communities in developing and managing marine resources in accordance with the potential, characteristics and sociocultural of the community (Wardhani, 2011; Pieter et al., 2015;Daindo Milla, 2017; Ahmad A, 2019). The active participation of coastal communities also gives hope for the alleviation of poverty problems that lead to the realization of justice and welfare of coastal communities (Karlina, 2015; Daindo Milla, 2017).

\subsubsection{Fishery Potential}

Coastal areas are a rich part of the potential of coastal, marine and fishery resources (Kristiyanti, 2016). Coastal areas also have potential that can be developed as marine tourism areas (Yuliana et al., 2013). People living in coastal areas, since long ago have also depended on the use of natural resources around the coast (Sujarwo et al., 2014). Over time, people's lives around the coast deteriorated (Yahya et al., 2013). The community has not been able to manage beach resources optimally (Muhtarom, 2017). The touch of knowledge about the utilization of resource development in coastal areas is very minimal (Ulfa, 2018). People don't know any other, more effective and innovative way to manage the coastal resources they produce (selvi Tebay, 2017). By looking at the problem, the economic growth of coastal communities should improve, but also ensure economic growth that can be enjoyed fairly and proposionally by all parties involved but can maintain the support capacity and quality of the coastal environment so as to preserve coastal areas (Wahyudin, 2016; Muliawan et al., 2016; Muhtarom, 2017).

\subsubsection{Farm Potential}

One type of business in the sub-sector of livestock that has the potential to be developed is beef cattle farming (Setiawan et al., 2013). Beef cattle are designated as the leading commodity of the livestock sub-sector in Kolaka Regency. In Kolaka Regency where beef cattle are widely maintained, especially in Watubangga Subdistrict (Pagala et al., 2019). Beef cattle businesses produce relatively large waste and potentially become a source of pollution (Munadi et al., 2019). Well-managed livestock waste can provide benefits for both farmers and the surrounding community (Solikin et al., 2019; Tembo et al., 2020).

\subsubsection{Potential Results of Food Crops, Plantations and Fisheries}

Efforts to meet the needs of domestic beef and milk need to be supported by improved feeding systems to increase the productivity of ruminants and to utilize local feed, including agricultural waste (Kuswandi, 2011; Susanty and Bachmid, 2016). But 
the reality is different, this great potential has not been utilized optimally. Currently only about $30-40 \%$ of agricultural and plantation waste has been used as feed (Irawan and Sutrisna, 2016; Prasiddha et al., 2016). Such waste is only in livestock commodity development areas or may be outside the livestock development area. Therefore, it is necessary to have an alternative source of local feed that is cheap, such as the utilization of agricultural waste as substitution feed (Kusumo et al., 2017; Ntelok, 2017). According to the report (Prasiddha et al., 2016), stating that the feed available throughout the year can be efficiently utilized by livestock and can be obtained at competitive costs is an ideal condition and a challenge in a livestock business. Wantasen et al., (2019), added that livestock businesses are utilizing available resources at no cost or at least at minimum cost especially in terms of meeting the needs of animal feed.

Furthermore, Faesal et al., (2017), reported that food crop waste has considerable potential as a source of ruminant animal feed. The advantages of food crop waste utilization programs for farms are one of them is to reduce the impact of environmental damage. Most Indonesian farmers have a habit of piling up, letting it rot or burn the waste after harvesting without prior treatment (Junedi and Endriani, 2013; Rusdiana, 2020). Kusumo et al., (2017), reported the use of food waste for animal feed has a major function in agricultural conservation programs. Traditional breeders cannot rely on lawns to meet their feed needs, due to limited land ownership and grass not available all year round (Abidin, 2013). One way for people's livestock businesses to survive is by utilizing food waste as a source of forage feed (Tanuwiria et al., 2006). The reason farmers use food waste as feed is at the time of harvesting abundant availability, so that it can be given in fresh form while overcoming the difficulty of feed during the dry season (Susilawati et al., 2014; Grace et al., 2014; Hapsoh et al., 2018; Umboh et al., 2019).

According to Gusnar (2014) the integration of cattle in oil palm plantations is one effective way to increase food productivity in the form of vegetables and animals. There are several impacts of livestock integration systems. Working on land with various components of crop and livestock types in an integrated manner (Ansari et al., 2014; Munandar et al., 2015; Lukiwati et al., 2019). Integrated agriculture can be an economic strategy to maintain the lives of farmers' households (Prajanti and Susilowati, 2016). Integration between crops and livestock can be applied in food crop agroecosystems and plantation agroecosystems, including oil palm and sugar cane crops (Ilham et al., 2014). The integration system of livestock crops plays a very important role so that nothing is wasted, the product of one system becomes input for another (Gupta et al., 2012; Puastuti, 2013; Ilham et al., 2014).

Increased demand for protein sources for animal feed, especially fishmeal, is becoming a problem in the future. Alternative protein sources are needed to meet the needs of amino acids to maintain livestock production (Wardhana, 2016). The results showed that waste produced from fishery businesses (catching, cultivating, processing) and non-fishery businesses are largely not optimally utilized (Luhur et al., 2016). Waste produced from the fishing effort is solid waste in the form of fish waste from demolition with the status has been utilized for poultry feed (Sihite, 2013). Waste from the processing business, among others, solid waste in the form of leftover fish head, stomach contents and bones with untapped status due to limited knowledge and skills in adopting technology (Hamim \&Vianda, 2019). Waste from cultivation efforts in the form of solids that have been used as compost fertilizer, while waste from the cultivation of soka crabs has not been utilized (Nurilmala et al., 2018). Types of businesses that have the potential to be developed by utilizing such waste are: 1) 
fishmeal businesses; 2) business of making fish and poultry feed; 3) efforts processed snacks (snacks) fish bones; 4) business of handicraft accessories in the form of bags or wallets; 5) business of making citosan raw material flour.

\subsection{Integration of Food and Livestock Crops}

Waste from rice plants is very useful to be used as animal feed. The waste is straw, bran, and bran. According to Anggraeny et al., (2017) Rice straw can be used as ruminant animal feed. The use of hay as animal feed has been common in tropical areas, especially as fodder in the dry season. While Hadipernata et al., (2012) according to Bran is a byproduct of the rice milling process that can be used more optimally into bran oil that has a high nutrient content.

Rice straw is a source of fiber feed while bran can serve as a source of fiber and / or energy. Rice straw is found in almost all regions in Indonesia so it is quite potential to be used as feed (Yusriani et al., 2015). Rice milling waste is bran, already commonly used as animal feed material. The nutritional variation of rice bran depends on the type of rice and the type of grinding machine but should be classified as an energy source. Generally, the better the quality of rice bran, the easier it is rancid. Good quality rice bran is easily contaminated by bacteria and fungi producing lipase enzymes. (Supriyatna and Putra, 2017; Rahayu et al., 2018; Handayani et al., 2019; Zulaikhah et al., 2020).

The follow-up of corn crops is part of the corn crop that is above ground, excluding milestones and roots that are on the surface and have been reduced seeds selected (Yulistiani, D., W. Puastuti, 2012). The number of corn follow-up products can be obtained from a unit area of corn crops between 2.5-3.4 tons of dry material per hectare that is able to provide raw materials for fiber sources / forage accommodation for 1 unit of livestock with a living weight equivalent to $250 \mathrm{~kg}$ with the consumption of dry feed $3 \%$ live weight. The process of grinding corn in the food and feed industry can be done through two ways, namely dry and wet milling, and each will provide different side results (Yenni Yusriani and Susanti, 2016; Medi and Junaidi, 2016; Afriani and Seftiadi, 2019). Feed ingredients of cassava origin are classified as a source of carbohydrates that are easily digestible. It has been proven, that the feed ingredients of cassava origin have better biological benefits compared to low to medium quality rice bran (Purnamaningsih et al., 2017). In recent years, the price of onggok has increased sharply and has exceeded the price of rice bran which has proximately had a higher PK rate (Idaryani, 2015).

All the results of cassava processing both dry and wet can be used as feed, including tuber skin, onggok (gamblong), gaplek (cassava chips) afkir and so on. Often cassava is deliberately processed as a cow feed material in the form of gaplek and pellets, this material is usually an export commodity (Mirzah and Muis, 2016; Sabri et al., 2017). Soybean straw is rarely used as feed, allegedly because the soybean harvesting process requires hay to be dried. Dry soybean straw is hard textured and dusty so that cattle do not like, as a single feed, dry soybean straw will lose the live weight of cows. Soybeans are one of the feed ingredients of high biological value (Cahyani et al., 2012; Suharyono, 2014).

The use of soybeans as ruminant animal feed has not been commonly used in Indonesia because it is expensive, competing with the needs of food and monogastric livestock (Adriani, 2017; Widarko and Humaidah, 2018; Krisnadianto, 2019). The result of soybean follow-up that is widely used as ruminant animal feed is fruit skin (pods), stems and pod skins, seed bark, tofu pulp, soy sauce pulp and soybean afkir 
(Kusumaningrum et al., 2018; Widyawati, 2017; Zakaria, 2016). Soybeans and their follow-up can be used to the fullest extent possible, depending on the availability and price of the ingredients at the local location. Tofu pulp, and seed bark are very well given to nursing or fattening cows (Wardhana, 2016; Krisnadianto, 2019).

Peanut straw is usually given in fresh form, after which old enough pea pods are taken. In addition to straw, the result of peanut cultivation can be in the form of meal, is a waste of nut pressing to be taken oil. The other follow-up results are pea skin and pea ari skin. The crude fiber content of pod skin is high, but low in protein and energy, while ari skin contains protein and balanced energy but contains many tannins that can decrease digestiility (Laikha et al., 2019). The use of peanut skin as animal feed has not been commonly done mostly just discarded or burned (Yenni Yusriani and Susanti, 2016). The use of peanut skin for breeding, enlargement, and fattening cow rations can reach $20 \%$ in rations (Laikha et al., 2019).

\subsection{Integration of Plantation and Livestock Crops}

Integrated agricultural system is an agricultural system that integrates the activities of sub-sectors of agriculture, crops, livestock, fish to improve the efficiency and productivity of resources (land, people, and other growing factors) independence and welfare of farmers in a sustainable manner. Integrated agricultural system is a system of management of plants, animals and fish with their environment to produce a product that is oftimal and closed cendrung to outside inputs. Integrated trading reduces the risk of pane failure, because dependence on a commodity can be avoided and cost-effective production. Integrated agricultural system of crops and livestock is an agricultural system characterized by a close relationship between the components of crops and livestock in a farming activity or in a region. Pointing out from the above, there have been many programs to increase the income of farmers farmers referring to the integration program of crops and livestock. Livestock can act as a biological industry while also being able to increase meat production and at the same time composting providers.

One of the efforts to realize a sustainable farming system is by developing farming patterns by paying attention to land ecosystems and paying attention to the potential of a region (Martin et al., 2016). Integrated agricultural pattern is cattle and crop business is expected to help realize a sustainable agricultural system of diversification of farming and livestock is also expected to improve the welfare of the community (Sujana et al., 2016). Integrated agricultural system (livestock crops) is to integrate all components both vertically and horizontally by utilizing all the potentials (Hadija et al., 2016).

Integrated farming system of livestock crops determines the success of products that can compete in the market, while opening job opportunities and providing income for farmers (Marjaya, 2016; Hidayat, 2016). The agricultural sector is still a major mainstay in national development, related to efforts to realize and maintain food security, provide jobs and community welfare, and meet various needs of industrial raw materials (Kusumo et al., 2017).

Plants that are integrated with cattle are able to utilize follow-up products and plant byproducts (remnants of crop yields) for animal feed and vice versa cattle can provide raw materials for organic fertilizer as a source of nutrients needed by plants (Dewi et al., 2019). The direct advantage of the integration of cattle-food crops is the increase in the income of livestock farmers from the sale of cattle and corn. Indirect advantage is the improvement of soil quality due to the provision of manure (Sun et al., 
2019). The use of manure as organic fertilizer in the complementary system of livestock-crops is proven to have been able to increase the productivity and income of farmers and reduce production costs (Holland, 2020). On the other hand, organic agricultural products have a brighter prsfek compared to agricultural products that are loaded with anrganik materials. Therefore, farmers should implement a complementary system of livestock crops.

\subsection{Integration of Fisheries and Livestock}

The transfer of agricultural land to non-agricultural land such as settlements is one of the main problems in agriculture. On the other hand, the increase in the population will have an impact on the increasing need for agricultural materials. An effective and efficient agricultural system model is needed for improving agricultural productivity (Rauf \&Rahmawaty, 2013). Farming of crops, livestock, and fisheries produces various types of waste that can pollute the environment if not managed properly (Amri \&Y, 2014). Therefore, agricultural waste management needs to be done in order to reduce environmental pollution while minimizing energy inputs from outside the system so as to improve the efficiency of farming and food security of a region (Yani \&Sujono, 2014; Sudarman et al., 2014; Hendalia et al., 2016). One way to apply this concept to a farm is to implement the Plant-Livestock-Fish Integration System (SITTI) (Atria et.al., 2017). The results of The Saputra study (2018) reported that the SITTI model has a higher output/input ratio value than non-SITTI agriculture.

Problems in brackish water cultivation include aquaculture activities have a significant impact on mangrove hydrology (Yuliana et al., 2013). Many mangrove forests are left surrounded by embankment banks, blocked from the tides (Zakiyah, 2014). In Indonesia this system is also called "intercropping pond" which means brackish pond with many plants (Arifin \&Kepel, 2016). This system in Indonesia aims to minimize costs, increase farmers' incomes, and preserve mangrove forests (Juwita et al., 2015;Ditya et al., 2017; Pringgenies et al., 2017).

\section{CHAPTER III RESULTS AND DISCUSSION}

\subsection{Small Islands Kolaka Regency}

Kolaka Regency was formed based on Law No. 59 of 1959. Since its establishment as a regency until now, Kolaka Regency has twice been expanded into a new autonomous region namely North Kolaka Regency and East Kolaka Regency. Astronomically, Kolaka Regency is located on the southern part of the equator, extending from North to South between $3^{\circ} 36^{\prime}-4^{\circ} 35^{\prime}$ South Latitude (LS) and stretching from West to East between $120^{\circ} 45^{\prime}-121^{\circ} 52^{\prime}$ East Longitude (E). Based on its geographical position, the boundaries of Kolaka Regency are north bordered by North Kolaka Regency, south side bordered by Bombana Regency, east bordering East Kolaka Regency, and west bordering South Sulawesi Province in Bone Bay (Kolaka Regency Statistics Agency, 2020).

Most of Kolaka is a marine area, about $\pm 15,000 \mathrm{~km} 2$. While the land area is $3,283.59 \mathrm{~km} 2$. Kolaka regency consists of 12 sub-districts. If sorted from the widest, the largest sub-districts are Samaturu (22.65\%), Wolo (11.97\%), Watubangga $(10.91 \%)$, Iwoimendaa (8.77\%), Tanggetada (8.40\%), Pomalaa (8.8\%), Pomalaa (8 Latambaga Subdistrict (7.69\%), Wundulako Subdistrict (5.64\%), Kolaka Subdistrict (4.34\%), Polinggona Subdistrict (4.26\%), Baula District (3.68\%), And Toari Subdistrict (3.64\%) Most of Kolaka is a marine area, about $\pm 15,000 \mathrm{~km} 2$. While the land area is 3,283.59 
km2. In Kolaka Regency there are island islands scattered in each sub-district. The island in Kolaka Regency is; Padamarang Island, Large Lambasina Island, Small Lambasina Island, Maniang Island, Crocodile Island, Lemo Island, Banana Island, Laburoko Island, Lima Island, and Ijo Island (Kolaka District Statistics Agency, 2020).

\subsection{Agricultural Resources of Kolaka Regency}

Kolaka regency has a variety of agricultural land and is divided into categories including rice fields, plantation land, tegal land and farmland. Some of the agricultural land in Kolaka Regency Food crops cultivated in Kolaka Regency in 2019 are only seven main types of crops, namely: rice paddy fields, cassava, cassava, corn, peanuts, green beans, and soybeans. Meanwhile, rice paddy production in Kolaka Regency amounted to 85,877.14 tons. For cassava plants, production in Kolaka Regency amounted to 7,773.60 tons. The largest plantation commodity in Kolaka Regency is patchouli reaching $15,782.14$ tons. Then followed by cocoa commodity with production with 9,454.24 tons in 2019 (Kolaka District Statistics Agency, 2020).

\subsubsection{Farm}

Meat production from farm animals in Southeast Sulawesi in 2017 showed an increase from the previous year, from 18,821,116 kg in 2016 to 21,057,951 kg in 2017. The increase in meat production, including production for beef, from 4,412,704 $\mathrm{kg}$ to $5,103,796 \mathrm{~kg}$. Livestock population data is sourced from the Directorate General of Livestock and Animal Health of the Ministry of Agriculture, while the number of livestock slaughter is the result of the Livestock Slaughter Report Survey. The collection of livestock slaughter data is conducted in full every quarter throughout slaughterhouses (RPH) and slaughterhouses Kolaka District (still incorporated with East Kolaka Regency) Livestock Production of livestock meat in Kolaka District in 2015 showed an increase from the previous year of 1,051,060 Kg in 2016 to 855,923 $\mathrm{Kg}$ in 2017. Bali cattle population by sub-district in Kolaka Regency can be presented in Table 1.

Table 1. Bali Cattle Population in Kolaka Regency, 2020

\begin{tabular}{clccc}
\hline \multirow{2}{*}{ No } & \multicolumn{1}{c}{ District } & Male & Number of Cattle Population bali & Total \\
\cline { 3 - 4 } & & 471 & 621 & 1.092 \\
1 & Kolaka & 417 & 490 & 907 \\
2 & Latambaga & 763 & 1.915 & 2.678 \\
3 & Samaturu & 666 & 984 & 1.650 \\
4 & Wolo & 438 & 672 & 1.110 \\
5 & Iwoimendaa & 481 & 841 & 1.322 \\
6 & Wundulako & 433 & 686 & 1.119 \\
7 & Baula & 390 & 778 & 1.168 \\
8 & Pomalaa & 624 & 1.714 & 2.338 \\
9 & Tanggetada & 1.050 & 2.384 & 3.434 \\
10 & Polinggona & 1.766 & 6.756 & 8.522 \\
11 & Watubangga & 762 & 2.953 & 3.715 \\
12 & Toari & $\mathbf{8 . 2 6 1}$ & $\mathbf{2 0 . 7 9 4}$ & $\mathbf{2 9 . 0 5 5}$ \\
\hline \multicolumn{2}{c}{ Total } & & &
\end{tabular}

Table 1 data shows that the population of bali cattle in Kolaka Regency in 2018 amounted to 29,055 heads divided into two types, namely males and females while the male livestock population amounted to 8,261 heads and females 20,794 heads. The population is divided into several sub-districts, among others Kolaka subdistrict with a total population of 471 males and females 621 heads, Latambaga Subdistrict 417 males while females 490 heads with a total of 907 heads. Samaturu subdistrict has a male 
livestock population of 763 and females numbering 1,915 with a total of 2,678, Wolo subdistrict has a population of 666 bulls and 984 cows with a total of 1,650, Iwoimendaa has a population of 1,110 with a total population of 438 males and females have a population of 672 , Wundulako subdistrict has a male livestock population of 481 heads and females with a population of 841 heads with a total of 1,322 heads, Baula Subdistrict has a population of 433 cattle and a population of 686 female cattle with a total population of 1,119 heads divided into 3 parts, namely children, young and adults.

In accordance with the data taken from the department of plantation and livestock Kolaka district shows that the population of bulls in Pomalaa Subdistrict 390 heads and heifers numbered 778 heads with a total of 1,168 heads, Tanggetada subdistrict has a total population of 624 male cattle and female cows numbered 871 heads with a total population of 2,338 heads spread in several villages that entered the administration of Tanggetada Subdistrict, Polinggona subdistrict is a sub-district that is in conjunction with Tanggetada Subdistrict and is a fraction of Watubangga Subdistrict with a total population of 1,050 bulls and 2,384 cows, so that it has a total of 3,434 heads spread across several villages in Polinggona Subdistrict, Watubangga Subdistrict is the district with the largest population of Bali cattle cattle among the number of bali cattle population in several districts located in wila well kolaka regency administration, the number of cattle population of bali bulls denounced Watubangga numbered 1,766 heads and the number of female bali cattle amounted to 6,756 heads so that the total population of bali cattle in Watubangga subdistrict is 8,522 heads scattered in several villages. Meanwhile, toari sub-district has a total of 762 bulls and 2,953 heifers with a total population of 3,715 .

\subsubsection{Plantation}

\section{Oil Palm Plantation}

Palm oil is an industrial plant as a raw material producing cooking oil, industrial oil, and fuel. Palm oil has an important role in the oil industry that can replace coconut as its source of raw materials. The plantations generate huge profits so many forests and old plantations are converted into oil palm plantations. Indonesia is the world's largest palm oil producer.

Palm oil is an industrial plant as a raw material for producing cooking oil, industrial oil, and fuel. The plantations generate huge profits so many forests and old plantations are converted into oil palm plantations. There are several species of oil palm, namely E. guineensis Jacq., E. oleifera, and E. odora. Varieties or types of palm oil are classified based on two characteristics, namely the thickness of the endocarp and the color of the fruit. Based on the thickness of the endokarp, palm oil is classified into three varieties namely Dura, Pisifera, and Tenera, while according to the color of the fruit, palm oil is classified into three varieties namely Nigrescens, Virescens, and Albescens. In general, palm oil consists of several parts, namely roots, stems, leaves, flowers and fruits. The part of palm oil that is turned into oil is fruit. The productivity of oil palm plantations in Kolaka Regency by sub-district in Kolaka Regency can be presented in Table 2. 
Tabel 2. Palm Oil Plantation Productivity Kolaka Regency

\begin{tabular}{|c|c|c|c|c|c|c|}
\hline \multirow[b]{2}{*}{ No } & \multirow[b]{2}{*}{ District } & \multicolumn{4}{|c|}{ Area Broad (Ha) } & \multirow{2}{*}{$\begin{array}{c}\text { Production } \\
\text { (Kg) }\end{array}$} \\
\hline & & TBM & TM & $\begin{array}{c}\text { TTM } \\
\text { (TTR) }\end{array}$ & Total & \\
\hline 1 & Watubangga & 94.50 & 320.00 & - & 414.50 & 231.520 \\
\hline 2 & Tanggetada & 696.50 & 821.50 & - & 518.00 & 101.222 \\
\hline 3 & Toari & 325.00 & - & - & 325.00 & - \\
\hline 4 & Polinggona & 175.50 & 1.50 & - & 177.00 & 267 \\
\hline 5 & Pomalaa & 102.90 & 3.50 & - & 106.40 & 1.399 \\
\hline 6 & Wundulako & 461.40 & 523.00 & 9.05 & 993.45 & 18.275 \\
\hline 7 & Baula & 226.75 & 504.75 & 4.50 & 736.00 & 164.750 \\
\hline 8 & Kolaka & 425.00 & 922.50 & - & 1347.00 & 223.372 \\
\hline 9 & Latambaga & 881.17 & 2210.83 & - & 3092.00 & 1.826 .600 \\
\hline 10 & Samaturu & 463.62 & 1474.98 & 18.82 & 1957.42 & 1.250 .000 \\
\hline 11 & Wolo & 208.35 & 1240.00 & - & 1448.35 & 1.068 .000 \\
\hline 12 & Iwoimendaa & 216.00 & 1269.00 & - & 1485.00 & 1.062 .000 \\
\hline \multicolumn{2}{|c|}{ Total } & 4276,69 & 9291,56 & 32,37 & 13600,62 & 5947404 \\
\hline \multicolumn{2}{|c|}{2017} & 3596,84 & 9258,11 & 32,37 & 12887,32 & 6843012 \\
\hline \multicolumn{2}{|c|}{2016} & 3087,26 & 9075,14 & 32,37 & 12194,77 & 7203062 \\
\hline
\end{tabular}

Source : Kolaka District Statistics Agency, 2020.

Based on table 8 data shows that Watubangga subdistrict has an area of plantation area of 414.50 ha with the division of plants has not produced an area of 94.50 ha and plants produce an area of 320.00 ha with a total production of $231,520 \mathrm{~kg}$. As for Tanggetada Subdistrict, the plant has not produced an area of 696.50 ha with plants producing an area of 821.50 ha with a total area of 518.00 ha followed by a total production of $101,222 \mathrm{~kg}$. Toari subdistrict has an area of plants has not produced an area of 325.00 ha. However, Polinggona subdistrict instigated an area of 175.50 ha and has not produced 1.50 ha with a total of 177.00 ha with a total production of $267 \mathrm{~kg}$. As for Pomalaa Subdistrict, the plant has not produced 102.90 ha and the plant produces 3.50 ha with a total of 106.40 ha with a production of $1,399 \mathrm{~kg}$. Furthermore, in Wundulako subdistrict the plant has not produced 461.40 ha and the plant produces 523.00 ha. However, Wundulako sub-district has a total area of oil palm plantations that do not produce at all an area of 9.05 ha so that the number of oil palm plantation areas located in Wundulako Subdistrict covers an area of 993.45 ha with the amount of production in 2020 as much as 18,275 kg. By looking at the productivity data of oil palm plantations in Baula sub-district shows that the crop has not produced an area of 226.75 ha while for the plant to produce the district baula has an area of 504.75 ha. However, in Baula sub-district has an area of oil palm plantations that do not produce at all with an area of 4.50 ha so that the area of oil palm plantations in Baula subdistrict is a total area of 736.00 ha with a total production of 164,750 ha.

Oil palm plantations in Kolaka sub-district have an area of oil palm plantations crops have not produced an area of 4.25 .00 ha while for plants produce an area of 922.50 ha with a total amount of 1347.00 ha with a total production of 223,372 kg. Meanwhile, for Latambaga sub-district has an area of oil palm plantations divided into two categories, namely crops have not produced an area of 881.17 ha and instigated plants covering an area of 2210.83 ha with a total of 3092.00 ha and the amount of production produced $1,826,600 \mathrm{~kg}$ in 2020 . 
The area of oil palm plantations in Samaturu sub-district is divided into two parts, namely the crop has not produced an area of 463.62 ha and the plant produces an area of 1474.98 ha and the plant does not produce an area of 18.82 ha with a total of 1957.42 ha. Palm oil production in Samaturu sub-district as much as 1,250,000 kg. For Wolo subdistrict, the area of oil palm plantation covers an area of 1448.35 ha with a total production of $1,068,000 \mathrm{~kg}$ which is divided into two parts, namely the crop has not produced an area of 208.35 ha and the plant produces 1240.00 ha. Iwoimendaa subdistrict is one of the sub-districts located in Kolaka Regency with an area of oil palm plantations divided into 2 (two) parts, namely crops have not produced an area of 216.00 ha and plants produce 1269.00 ha with a total of 1485.00 ha and total production in 2018 as much as 1,062,000 kg.

\section{People's Coconut Plantation}

Each hectare of plantation area is at least able to provide feed materials for livestock, all year round. Plantation production by Sub-District in Kolaka Regency (thousand tons), presented in Table 3.

Table 3. Area, Production, and Number of Household Heads Working on Coconut Crops by District in Kolaka Regency, 2017.

\begin{tabular}{|c|c|c|c|c|c|c|}
\hline & \multicolumn{4}{|c|}{ Area Broad (Ha) } & \multirow{2}{*}{$\begin{array}{l}\text { Total } \\
\text { KRT }\end{array}$} & \multirow{2}{*}{$\begin{array}{l}\text { Production } \\
\text { (Kg) }\end{array}$} \\
\hline & TBM & TM & TTM/TTR & Total & & \\
\hline Watubangga & 554.50 & 213.50 & 44.00 & 812.00 & 804.00 & 217750,00 \\
\hline Toari & 71.00 & 211.50 & - & 282.50 & 838.00 & 305617,50 \\
\hline Tanggetada & 160.90 & 582.57 & - & 743.47 & 695.00 & 675300,00 \\
\hline Polinggona & 18.00 & 70.50 & - & 88.50 & 158.00 & 82125,00 \\
\hline Pomalaa & 2.10 & 23.75 & - & 25.85 & 188.00 & 25240,00 \\
\hline Wundulako & 112.00 & 76.17 & 2.80 & 190.97 & 335.00 & 97497,60 \\
\hline Baula & 3.50 & 56.98 & - & 60.48 & 223.00 & 37100,00 \\
\hline Kolaka & 31.50 & 19.00 & - & 50.50 & 379.00 & 11310,00 \\
\hline Latambaga & - & 31.50 & - & 31.50 & 88.00 & 47620,00 \\
\hline Samaturu & 131.97 & 574.93 & - & 706.90 & 945.00 & 697300,00 \\
\hline Wolo & - & 544.25 & - & 544.25 & 481.00 & 1062500,00 \\
\hline Iwoimendaa & - & 257.00 & - & 257.00 & 335.00 & 302500,00 \\
\hline Total & $1,085.47$ & $2,661.65$ & 46.80 & $3,793.92$ & 5469 & 3561860,10 \\
\hline 2015 & 1071,47 & 2683,30 & 38.55 & 3793,32 & 5466 & 3871313,48 \\
\hline 2014 & 877.78 & 2663,55 & 41.25 & 3582,58 & 5277 & - \\
\hline
\end{tabular}

Source: Plantation and Livestock Kolaka Regency, 2017

In an effort to meet sustainable food availability and make Indonesia the world's food granary, a comprehensive joint effort is needed in managing food resources. Production of each plantation komuditi is one of the prospects because automatically from the production will produce follow-up results so that this is an opportunity in the utilization as a source of animal feed.

\subsubsection{Fishery}

Fishing Catch erier over fish in the sea and catch fish in public waters. Aquaculture aquaculture over aquaculture, ponds, ponds, caramba, floating nets, and rice fields. Household Aquaculture Fisheries households that conduct fish farming activities in that way a lot/results for sale. Area of Aquaculture by Sub-District in Kolaka District is presented in Table 4. 
Table 4. Area of Aquaculture by Sub-District in Kolaka Regency, 2017 (Ha)

\begin{tabular}{lccc}
\hline \multirow{1}{*}{ Subdistric } & & Area of Aquaculture & Sresh water \\
\cline { 2 - 4 } & Brackish & Sea Water & 2.75 \\
Watubangga & 1315 & 0 & 0.00 \\
Toari & 189 & 19 & 2.50 \\
Tanggetada & 116 & 0 & 0.75 \\
Polinggona & 0 & 0 & 57.12 \\
Pomalaa & 369 & 40 & 17.42 \\
Wundulako & 784 & 71 & 39.38 \\
Baula & 57 & 0 & 1.65 \\
Kolaka & 0 & 24 & 4.75 \\
Latambaga & 377 & 88 & 1.07 \\
Samaturu & 1112 & 170 & 3.28 \\
Wolo & 431 & 503 & 0.33 \\
Iwoimendaa & 57 & 52 & $\mathbf{1 3 1}$ \\
\hline $\mathbf{2 0 1 6}$ & $\mathbf{4 8 0 7}$ & $\mathbf{9 6 7}$ & \\
\hline
\end{tabular}

Source: Marine and Fisheries Kolaka Regency, 2017.

\subsubsection{Food Crops}

Rice fields are farmland that is plot-based and limited by the pematang (galengan), a channel to hold / channel water, which is usually planted with rice fields regardless of where it is obtained or the status of the land. Rice field production of 12215.33 tons (ha) in 2017. Furthermore, for food crops in the form of cassava vines 86.56 tons (ha) in 2017 and cassava 285.67 tons (ha). Meanwhile, for peanut plant type 4.50 ton (ha) in 2017. The main data of food crops collected are the area of harvest and productivity (yield per hectare). Food crop production is the result of multiplication between the area of harvest and productivity. The collection of harvest area data is done every month with the approach of sub-district areas throughout the region in Kolaka Regency. Productivity data collection is done through direct measurement on tile plots measuring $21 / 2 \mathrm{~m} \times 21 / 2 \mathrm{~m}$. Productivity data collection is done every subround (four months) at the farmer's harvest time. Meanwhile, soybean production in 2017 amounted to 4.90 tons (ha), as well as the type of food crop komuditi in the form of green beans with the production of each hectare amounted to 3.16 tons (ha). Furthermore, in Kolaka Regency for the type of food crop komuditi in the form of corn has a production value of each hectare as much as 5.19 tons (ha) (Department of Food Crops and Horticulture Kolaka Regency, 2017).

\subsection{Agricultural Waste Utilization}

The large rate of population growth and high development activities reduce the amount of productive agricultural land due to the rampant land conversion. This is one of the obstacles with the depletion of productive agricultural land in each year. Integrated agricultural system is one of the alternatives in improving the production sector of both food crops and plantation crops, livestock, fisheries and forestry. Increasing environmental problems in line with the development of modern knowledge and technology in the field of agriculture in a broad sense, encouraging the birth of new issues and concepts such as sustainable agriculture, organic agriculture, environmentally friendly agriculture, low external input for sustainable agriculture, zero waste production system, sustainable food house concepts, all of which become great opportunities for the development of integrated agricultural systems.

\subsubsection{Waste Farms}

One type of business in the sub-sector of livestock that has the potential to be developed is beef cattle farming. Beef cattle are designated as the leading commodity of 
the livestock sub-sector in Kolaka Regency. Beef cattle businesses produce relatively much waste and potentially become a source of pollution (Setiawan et al., 2013). Livestock waste that is managed well livestock waste can provide benefits for both farmers and the surrounding community (Febriyanita, 2015; Bamualim et al., 2015). Current management of beef cattle waste as well as factors that encourage and hinder the management of cattle waste. The most influential factors on the status of waste management of beef cattle are environmental condition factors then the characteristics of innovation, management of livestock waste, and the influence of characteristic factors of farmers (Suherman \&Kurniawan, 2017; Marlina et al., 2019).

\subsubsection{Plantation Waste and Food Crops}

Efforts to meet the needs of domestic beef and milk need to be supported by improved feeding systems to increase the productivity of ruminants and to utilize local feed, including agricultural waste (Kuswandi, 2011; Indrayani \&Hellyward, 2015; Ruhiyat et al., 2020). Among the existing agricultural waste, new rice straw is used for feed, whereas waste of other food crops and plantation crops are abundant, both for basal feed and additional feed (Siswati \&Nizar, 2012; Sariubang et al., 2013; Suprihatin \&Sukardi, 2018). An estimated 151 million tons of dry forage food crop waste and 94.24 million tons of dry forage plantation waste are available and can support more than 183.18 million adult cows without having to rely on grass (Tumewu et al., 2014;Pomegranate et al., 2015). Therefore, technology is needed to improve palatability, consumption, digestibility of feed, efficiency of feed use, and formulation of feed to maximize livestock productivity (Nainggolan et al., 2018). Feed consumption can be improved by conditioning the environment at low temperatures, smoothing ingredients, increasing the frequency of feeding, as well as the distillation between basal feed and supplements (Abadi et al., 2019). Feed digestitude and efficiency of feed use can be improved by providing chemical or biological treatment as well as balancing energy, nitrogen and mineral sources (Ramdani et al., 2017). Complete feed of the manufacturer in the form of pellets on the basis of sources of fiber, protein, energy, and minerals from agricultural waste enriched with vitamins can be recommended for fattening (Muslim, 2017). By applying the technology of ruminant livestock business development needs to be integrated with food crops and plantation crops, agricultural waste processing industry, and supported by innovators of feed utilization technology to ensure the availability of quality feed throughout the year.

\subsubsection{Industrial Waste Fisheries}

The fishermen's catch before being sold and sent out of town, usually collected in tangkahan and fish auction place (Sugandi, 2016). In this place the fish are selected or sorted and selected according to consumer demand. The selection of fish produces fish waste that is generally in the form of fish with physical conditions are not worth selling, small fish that have low economic value and fish that are not worth consuming (unedible portion). Fish waste as mentioned above is usually stacked, and this buildup is often left too long to cause an unpleasant smell (Durand, 2010). To overcome the buildup too long, there have been several ways of handling and processing fish waste, among others used as materials to make terasi, processed into salted fish. However, until now fish waste still remains a problem, especially in terms of pollution or the stench produced. Nowadays the use of fishmeal as animal and livestock feed ingredients is increasingly popular. Fishmeal is a dry solid product produced by removing most of the liquid and some or all of the fat contained in the body of the fish. Fishmeal as animal feed and fish to meet the needs of animal protein is made from processed remains 
(waste) in maximizing the utilization of fish that ultimately also maximizes the economic value of processed waste (Sihite, 2013; Komariyati et al., 2018). Raw materials that should be used are lean fish to reduce the possibility of fat oxidation that will cause decay.

\subsection{Utilization of Small Islands and Coastal Areas in Kolaka Regency}

The pattern of livestock development refers to the concept of spatial areas while paying attention to the specific potentials of each island group which in its implementation is carried out through increasing population, products and added value of products and the main target is the improvement of superior livestock commodities based on local resources. Kolaka regency there are 10 (ten) islands divided into several sub-districts. This is one of the opportunities in the development of livestock centers, ecotourism centers, and fisheries and marine centers.

\subsubsection{Livestock Center}

Kolaka regency includes several areas have the potential to become a livestock development area in Southeast Sulawesi, both in the aspects of agroclirants and socioeconomic apegaan of the community. In this context, one of the efforts that can be made to facilitate the sustainable development of farms by identifying potential areas based on the size of resources used by the livestock sector. Therefore, to support this is done several ways, namely; (1) determine ruminant livestock commodities that can be seeded based on the support of regional resources owned by Kolaka Regency, especially livestock that can adapt to the archipelago environment and (2) identify micro areas that can be used as bases for livestock development.

One of the efforts to develop and develop the livestock sector in Kolaka Regency can be done by utilizing all resources owned. The resources available and can be utilized include natural resources, people and capital. The existence of livestock populations in an area is believed to be the result of the intercation of several dimensions contained within the region. Some of these dimensions include technology (production mode), economy and social conditions of society. These three dimensions interact to form an enabling environment that allows livestock populations to thrive. Therefore, optimization of the management of various resources available to ensure the sustainability of the environment is the first step that can be taken in the development of the livestock sub-sector in kolaka regency. Natural resources remain the main base of livestock business activities, especially for ruminant livestock. As a feed provider, the interrelationship between food production area and livestock production becomes an essence in the process of livestock development.

Food crops contribute significantly to the creation of an environment conducive to the livestock sector, especially in the context of providing feed sources. Spatial patterns of the spread and concentration of such livestock populations give at least two indications. First, the maintenance of livestock seems to be concentrated on narrowminded farmhouses. This indication indicates that the key to the development of farms especially in the context of population increase is in the household. It can also justify livestock businesses which in fact are complementary activities of farming as residues from the resources used. The second indication, with the rapid rate of conversion of agricultural land farm development opportunities will certainly be smaller if there are no efforts to anticipate the dynamics.

This concept, in addition to the integration between livestock production and food crops, also refers to the integration of the region between the agricultural sector in general and the non-agricultural sector (industry and services). In the long run any 
production activity that requires land as its main resource (such as livestock production) will be within the circle of the region. In the regional planning level, agricultural activities in the region become one of the main components in planning. In the context of livestock development in Kolaka Regency, some of these empirical findings can certainly justify the importance of specific areas intended for the development of livestock activities. Identification of areas that have the potential to become a base for livestock development seems to be one of the components in overall planning. Based on the previous concept framework, the terminology of potential areas for livestock development will refer to indicators of agricultural land availability, specialization of agricultural households and availability of infrastructure related to the livestock sector. Therefore, kolaka district government should use some islands in the administrative area as a center of livestock, especially ruminant livestock.

Therefore, in supporting the animal alignment system on the islands that become the center of livestock can utilize agricultural waste. Agricultural waste is feed sourced from food crop waste and its production is highly dependent on the type and amount of planting area of food crops in a wllayah. Agricultural waste is categorized as feed with high fiber and low protein. The types of feed that belong to this group are corn straw, rice straw, peanut straw and also feed with high coarse fiber and linggi protein. Feed that belongs to this category is some agricultural industrial waste such as rice bran, and corn bran, and so forth. So that the utilization of small islands located in Kolaka Regency can be realized as a center of livestock and agricultural follow-up products can be utilized optimally as a source of animal feed.

\subsubsection{Ecotourism Center}

Kolaka regency has sea waters covering an area of $15,000 \mathrm{~km} 2$ with a coastline length of $293.45 \mathrm{~km}$. this is one of the opportunities for the development of ecotourism centers because it is supported by the length of the coastline and 10 (ten) islands, currently there is only 1 (one) island that has been used as a tourism location by the kolaka regency government, namely lambasina island, in addition to the utilization of ecotourism the local government has utilized the island as a mining location. In the last few years some of these islands have been damaged, this is not in accordance with Law No. 27 of 2007, on The Management of Coastal Areas and Small Islands, clearly mentions, the management of coastal areas and small islands based on, sustainability, cohesion, partnership, equality, community participation, openness and justice.

Management of coastal areas and small islands with the aim, protecting, conserving, rehabilitating, utilizing, and enriching coastal resources and small islands and their ecological systems in a sustainable manner while creating harmony and synergy between communities and local governments in the management of coastal resources and small islands in strengthening community participation while encouraging community initiatives for coastal resource management $d$ small islands in order to achieve justice, balance, and sustainability. Thus, it can increase the social, economic, and cultural value of the community through the participation of the community in the utilization of coastal resources and small islands.

\subsubsection{Fisheries and Marine Center}

The purpose of the process of planning and managing coastal and marine areas is to be able to translate the concept of development which further becomes the basis for the establishment of coastal and marine development strategies. To be able to translate the concept of sustainable development into the practice of proper management of coastal resources, both ecological and socioeconomic and cultural aspects must be considered 
from the planning stage. Therefore, the uniqueness of coastal areas and small islands that are vulnerable to developing conflicts and limited access to utilization for coastal communities and small islands, needs to be managed properly so that the impact of human activities can be controlled and some coastal areas maintained for conservation. Communities need to be encouraged to manage their coastal areas well and those that have succeeded need to be incentivised, but the destructive ones need to be sanctioned.

Coastal resources and relatively rich small islands are often the center of economic growth and densely populated populations. However, most of the population is relatively poor and the poverty is putting pressure on the coastal resources and small islands that are the source of their livelihood. If ignored, it would implicate increased damage to coastal ecosystems and small islands. In addition, there is still a tendency that industrialization and economic development in coastal areas and small islands often marginalize the locals. Therefore, community empowerment norms are required. Coastal areas and small islands that are vulnerable to change need to be protected through management in order to be utilized to meet the needs of people's lives and livelihoods. Therefore, policies are needed in its management so that it can balance the level of utilization of coastal resources and small islands for economic benefit without compromising the needs of future generations through the development of conservation areas and coastal borders.

In formulating the direction of management of potential coastal resources, seen based on optimum characteristics that include coastal resources and land resources as an effort to improve the welfare of the community through the determination of coastal and land zones to identify the direction of activities and potential functions to be developed as well as the formulation of optimal spatial structures that consider aspects of quality and distribution of service centers and interrelationships between the centers in question and the improvement of functions and conditions of factors supporting the main activities in coastal and land areas. Coastal and marine area management is used as a tool to continuously drive production, processing, and/or marketing in the leading production centers pro small businesses, in the field of fishing catch, aquaculture fisheries, and processing and marketing.

\subsection{Conclusions}

\section{CHAPTER IV}

\section{CONCLUSIONS AND SUGGESTIONS}

In the writing of this paper there are several conclusions that can be obtained, among others as follows:

1. The pattern of livestock development refers to the concept of spatial areas while paying attention to the specific potentials on each island located in Kolaka Regency. As well as utilizing the potential of food crop and plantation follow-up in order to meet the needs of animal feed.

2. The system of cohesion between livestock and crops on small islands is to identify the type of forage that can grow well on the island as well as the followup of plantations and food crops to be maximized as animal feed.

3. The utilization of coastal and small islands can make a source of income for the community, because economic growth or exchange goes well in line with the utilization of the region into an ecotourism center. 


\subsection{SUGGESTIONS}

Kolaka District Government in the management of coastal areas and small islands should be able to protect, conserve, rehabilitate, utilize, and enrich coastal resources and small islands and ecological systems in a sustainable manner so that harmony and synergism between communities and local governments strengthen each other's role by encouraging community initiatives in the management of coastal resources and small islands in order to achieve justice, balance, and continuity. Thus, indirectly this can increase the social, economic, and cultural value of the community through the participation of the community in the utilization of coastal resources and small islands, especially the people of Kolaka Regency.

\section{REFERENCE}

Abadi, M., Nafiu, L. O., Karim, J., (2019). Pemetaan Potensi Sumberdaya Lahan Hijauan Pakan Ternak Sapi Bali Di Kecamatan Tinanggea Kabupaten Konawe Selatan. Jitro. Vol. 6 (1): 124-137.

Abidin, Z. (2013). Potensi Pengembangan Tanaman Pangan Pada Kawasan Hutan Tanaman Rakyat Potential Of Food Crops Development In Community Forest Area. J. Litbang Pert. Vol. 34 (2):71-78.

Adam, L., Sihombing, L., Pujiyanti, A., \& Haryanti, D. (2012). Wilayah Pesisir Dan Pulau-Pulau Kecil Di Indonesia. Wilayah Pesisir dan Pulau-Pulau Kecil di Indonesia. Jakarta: Pusat Pengkajian, Pengolahan Data dan Informasi (P3DI) Sekretariat Jenderal DPR Republik Indonesia dan Azza Grafika.

Adriani, L. (2017). Pemanfaatan Limbah Susu Kedelai Sebagai Pakan Ternak (Studi Kasus Di Desa Astanajapura Dan Desa Japura Kidul, Kecamatan Astanajapura. Jurnal Pengabdian Kepada Masyarakat. Vol. 4 (1): 209 - 211.

Afriani, T., \& Seftiadi, Y. (2019). Pemberdayaan Masyarakat Melalui Pelatihan Pembuatan Pakan Alternatif Amoniasi Jerami Jagung Di Nagari Pelangai Kaciak Kecamatan Ranah Pesisir, Pesisir Selatan. Jurnal Warta Pengabdian Andalas. Vol. 26 (2):81-87

Ahmad.A. (2019). Analisis Potensi Ekosistem Mangrove Sebagai Pengembangan Objek Wisata (Studi Kasus: Kabupaten Wakatobi). Prosiding Seminar Nasional. Vol. 4 (1): 177-186.

Amanah, S. (2004). Perencanaan Strategis Pengelolaan Sumberdaya Pesisir Terpadu Di Kelurahan Pulau Panggang Kecamatan Seribu Utara, Kabupaten Kepulauan Seribu Provinsi DKI Jakarta. Buletin Ekonomi Perikanan. Vol. 5 (2):1-16.

Amri, U., \& Y, Y. (2014). Efektivitas Pemberian Pakan Yang Mengandung Minyak Ikan Dan Olahanya Terhadap Fermentasi Rumen Secara In Vitro. Jurnal Ilmiah Ilmu-Ilmu Peternakan Universitas Jambi. Vol. 17 (1): 22-29.

Anggraeny, Y. N., Sukmasari, P. K., \& Mariyono, M. (2017). Suplementasi Dedak Padi Pada Pakan Berbasis Limbah Pertanian Terhadap Performa Sapi Peranakan Ongole: Studi Kasus Di Kelompok Ternak Kota Probolinggo. Teknologi Peternakan Dan Veteriner Mendukung Diversifikasi Sumber Protein Asal Ternak. Pros.Semnas.TPV-2017-P.140-147

Ansari MA, Prakash N, Baishya LK, Punitha P, Sharma PK, Yadav JS, Kabuei GP, Levis Ch Kl. 2014. Integrated Farming System: An ideal approach for developing more economically and environmentally sustainable farming systems for the Eastern Himalayan Region. Indian Journal of Agricultural Science. Vol. 84 (3): 356-362.

Anugrah, I. S., Sarwoprasodjo, S., Suradisastra, K., \& Purnaningsih, N. (2014). Sistem Pertanian Terintegrasi-Simantri: Konsep, Pelaksanaan, Dan Perannya Dalam Pembangunan Pertanian Di Provinsi Bali. Forum Penelitian Agro Ekonomi. Vol. 32 (2):157-176

Ari Atu Dewi, A. A. I. (2018). Model Pengelolaan Wilayah Pesisir Berbasis Masyarakat: Community Based Development. Jurnal Penelitian Hukum De Jure. Vol.18: 163-182

Arifin, T., \& Kepel, T. L. (2016). Analisis Ekologi-Ekonomi Pengembangan Minapolitan Perikanan Budidaya Di Provinsi Gorontalo. Jurnal Sosial Ekonomi Kelautan Dan Perikanan. Jsekp.Vol. 9 (2):12-17. 
Badan Pusat Statistik Kabupaten Kolaka. 2020. Luas Wilayah Kabupaten Kolaka. Kolaka.

Badan Pusat Statistik Kabupaten Kolaka. 2020. Sumber Daya Pertanian Kabupaten Kolaka. Kolaka

Bamualim, A. M., Madarisa, F., Pendra, Y., Mawardi, E., \& Asmak.(2015). Kajian Inovasi Integrasi Tanaman - Ternak Melalui Pemanfaatan Hasil Ikutan Tanaman Sawit Untuk Meningkatkan Produksi Sapi Lokal Sumatera Barat. Jurnal Peternakan Indonesia (Indonesian Journal of Animal Science). Jpi. Vol. 17 (2):83-93.

Cahyani, R. D., Nuswantara, L. K., \& Subrata, A. (2012). Pengaruh Proteksi Protein Tepung Kedelai Dengan Tanin Daun Bakau Terhadap Konsentrasi Amonia, Undegraded Protein Dan Protein Total Secara In Vitro. Animal Agricultural Journal. Vol. 1 (1): 159-166

Daindo Milla, D. A. S. (2017). Potensi Pemanfaatan Ekosistem Pesisir Pantai Labuhan Haji Lombok Timur Sebagai Daerah Ekowisata. Jurnal Biologi Tropis. Vol. 17 (1):388

Delima, M., Karim, A., \& Yunus, M. (2015). Kajian Potensi Produksi Hijauan Pakan Pada Lahan Eksisting Dan Potensial Untuk Meningkatkan Populasi Ternak Ruminansia Di Kabupaten Aceh Besar. Jurnal Agripet. Vol. 15 (1):33-40.

Dewi, P., Darmawan, S., Didi, R., \& B. Eymal, D. (2019). Farmers Household Strategy In Land Conversion Dynamics (Case Study Of Penrang District, Wajo Regency, South Sulawesi). International Journal of Scientific Research In Science And Technology. January. Hal. 278287.

Dinas Perkebunan dan Peternakan Kabupaten Kolaka. 2020. Populasi Sapi Bali di Kabupaten Kolaka. Kolaka.

Dinas Perkebunan dan Peternakan Kabupaten Kolaka. 2017. Luas Areal, Produksi, dan Jumlah Kepala Rumah Tangga yang Mengusahakan Tanaman Kelapa Rakyat menurut Kecamatan di Kabupaten Kolaka. Kolaka.

Dinas Kelautan dan Perikanan Kabupaten Kolaka. 2017. Luas Budidaya Perikanan menurut Kecamatan dalam Kabupaten Kolaka. Kolaka.

Dinas Tanaman Pangan dan Hortikultura Kabupaten Kolaka. 2017. Luas Luas Areal, Produksi, dan Jumlah Kepala Rumah Tangga yang Mengusahakan Tanaman Pangan menurut Kecamatan di Kabupaten Kolaka. Kolaka.

Ditya, Y. C., Adrianto, L., Dahuri, R., \& Susilo, S. B. (2017). Analisis Ekonomi-Ekologi Untuk Perencanaan Pembangunan Perikanan Budidaya Berkelanjutan Di Wilayah Pesisir Provinsi Banten. Jurnal Sosial Ekonomi Kelautan Dan Perikanan. Vol. 7 (2): 56-64.

Djamhur, M., Boer, M., \& Bengen, D. G. (2016). Pemodelan Interpretasi Struktural Pengembangan Kawasan Pesisir Dan Pulau-Pulau Kecil Di Teluk Weda. Interpretative Structural Modeling Of Coastal And Small Island Development In Weda Bay. Researchgate. Net. Hal. 127-140.

Durand, S. S. (2010). Studi Potensi Sumberdaya Alam Di Kawasan Pesisir Kabupaten Minahasa Selatan. Jurnal Perikanan Dan Kelautan Tropis. Vol. 6 (1):1-9.

Elysia, V. (2014). Kajian Pengelolaan Wilayah Pesisir Dan Pulau-Pulau Kecil Di Kabupaten Kaimana, Papua Barat. Jurnal Forum Ilmiah. Vol. 11 (3):334-343.

Fadlina, I. M., Supriyono, B., \& Soeaidy, S. (2013). Perencanaan Pembangunan Pertanian Berkelanjutan (Kajian Tentang Pengembangan Pertanian Organik Di Kota Batu) Sustainable Development Of Agrocultural (Studies On Organic Agricultural Development In Batu City). J-Pal, Vol. 4 (1):43-57.

Faesal, Dj, N., \& Soenartiningsih. (2017). Seleksi Efektivitas Bakteri Dekomposer Terhadap Limbah Tanaman Jagung. Penelitian Pertanian Tanaman Pangan. Vol. 1 (2): 105- 114

Fahriansyah, \& Yoswaty, D. (2012). Pembangunan Ekowisata Di Kecamatan Tanjung Balai Asahan, Sumatera Utara : Faktor Ekologis Hutan. Jurnal Ilmu Dan Teknologi Kelautan, Vol. 4 (2):346-359.

Fajri Chikmawati, N. (2019). Pengelolaan Wilayah Pesisir Dan Pulau-Pulau Kecil Di Indonesia (Dalam Perspektif Perlindungan Hukum Bagi Hak-Hak Ekonomi Masyarakat Tradisional). ADIL: Jurnal Hukum. Vol. 4 (2):396-402

Febriyanita, W. (2015). Pengembangan Biogas Dalam Rangka Pemanfaatan Energi Terbarukan Di Desa Jetak Kecamatan Getasan Kabupaten Semarang. Skripsi. 
Fyka, S., Yunus, L., Limi, M., Hamzah, A., \& Darwan, D. (2018). Analisis Dampak Pengembangan Wisata Pulau Bokori Terhadap Kondisi Sosial Ekonomi Masyarakat Bajo (Studi Kasus Di Desa Mekar Kecamatan Soropia). Habitat. Vol. 29 (3):106-112.

Gusnar. 2014b. Produktivitas Integrasi Kelapa Sawit dan Sapi di Labuhan Batu. BPP. Kecamatan Bilah Hilir. Labuhan Batu (Dikutip dari: Sumut/ANTARA/Online/15 Februari 2014).

Gupta, V., P.K. Rai, and K.S. Risam. 2012. Integrated crop-livestock farming systems: a strategy for resource conservation and environmental sustainability. Indian Research Journal of Extension Education, Special Issue. 2:49-54.

Hadija, H., Ikawati, I., \& Nirawati, N. (2016). Kajian Potensi Pengembangan Teknologi Sistem Integrasi Tanaman Jagung Dan Ternak Model Zero Waste Di Kabupaten Soppeng. Agrotan. Vol. 2 (2):68-84.

Hadipernata, M., Supartono, W., \& A.F. Falah, M. (2012). Proses Stabilisasi Dedak Padi (Oryza Sativa L) Menggunakan Radiasi Far Infra Red (FIR) Sebagai Bahan Baku Minyak Pangan. Jurnal Aplikasi Teknologi Pangan. Vol. 1 (4):103-107.

Haerani, H., (2012). Pengembangan Kawasan Ekowisata Di Pulau Maitara Kota Tidore Kepulauan. Jurnal Perencanaan Wilayah dan Kota. Vol. 2 (1): 39-46.

Hamim, S., \& Vianda, L. (2019). Strategi Pembangunan Kontekstual Terpadu Sektor Perkebunan, Pertanian, Peternakan, Perikanan Dan Industrialisasi Pengolahan Menjadi Pakan Ternak Dan Ikan. PUBLIKA: Jurnal Ilmu Administrasi Publik. Vol. 5 (2): 206-216.

Handayani, R. S., Ismadi, I., \& Kasmiran, A. (2019). Pemberdayaan Masyarakat Melalui Pembuatan Jerami Fermentasi Untuk Pakan Ternak Sapi Di Kecamatan Muara Batu Aceh Utara. BAKTIMAS : Jurnal Pengabdian Pada Masyarakat. Vol. 1(1):42-48.

Hapsoh, H., Wawan, W., \& Dini, I. R. (2018). Pengelolaan Tata Air Untuk Mendukung Pertanian Terpadu Di Desa Langsat Permai Kecamatan Bunga Raya Kabupaten Siak. Jurnal Pengabdian Kepada Masyarakat. Jpkm. Vol. 24 (1): 522-526.

Hendalia, E., Manin, F., \& Insulistyowati, A. (2016). Produksi Pakan Konsentrat Dan Tepung Berprobiotik Berbasis Ikan Rucah Di Kabupaten Tanjung Jabung Barat. Ekspose Hasil Penelitian Dan Seminar Pangabdian. Vol. 1 (1): 236-224.

Hidayat, N. (2016). Keberlanjutan Sistem Usahatani Integrasi Tanaman-Ternak Pasca Bencana Alam Gempa Bumi Di Daerah Istimewa Yogyakarta. Sains Peternakan, Vol. 7: (1):30. Https://Doi.Org/10.20961/Sainspet.V7i1.1014.

Holland, J. (2020). Integrated Farming Systems. Managing Soils And Terrestrial Systems, Vol. 4. (9): 171-175.

Idaryani. (2015). Teknologi Produksi Ubi Kayu Melalui Sistem Integrasi Tanaman-Ternak Sebagai Sumber Bahan Baku Bioetanol. Pertanian-Bioindustri Berbasis Pangan Lokal Potensial. Vol. 6 (1): 27-36.

Ilham, N., Saptana, B. Winarso, H. Supriadi, Supadi, dan Y.H. Saputra. 2014. Kajian Pengembangan Sistem Pertanian Terintegrasi Tanaman-Ternak. Laporan Penelitian Teknis. Bogor: Pusat Sosial Ekonomi dan Kebijakan Pertanian.

Indrayani, I., \& Hellyward, J. (2015). Optimalisasi Produksi Dan Maksimalisasi Keuntungan Usaha Ternak Sapi Potong Dengan Sistem Integrasi Sapi-Sawit Di Kabupaten Dharmasraya. Jurnal Peternakan Indonesia (Indonesian Journal Of Animal Science), Vol. 17 (3):187-194.

Irawan, B., \& Sutrisna, N. (2016). Prospek Pengembangan Sorgum Di Jawa Barat Mendukung Diversifikasi Pangan. Forum Penelitian Agro Ekonomi. Fae.Vol. 29 (2):99-113.

Junedi Dan Endriani, H. (2013). Introduksi Teknologi Pertanian Ramah Lingkungan Berbasis Reuse, Reduce Dan Recycle (3r) Dalam Meningkatkan Pendapatan Petani. Jurnal Pengabdian Pada Masyarakat. Vol. 5 (1): 90-100.

Juwita, E., Soewardi, K., \& Yonvitner, Y. (2015). Kondisi Habitat Dan Ekosistem Mangrove Kecamatan Simpang Pesak, Belitung Timur Untuk Pengembangan Tambak Udang (Habitat Conditions And Mangrove Ecosystem In Simpang Pesak District, East Belitung For Development of Shrimp Pond). Jurnal Manusia Dan Lingkungan. Https://Doi.Org/10.22146/Jml.18725.

Karlina, E. (2015). Strategi Pengembangan Ekowisata Mangrove Di Kawasan Pantai Tanjung Bara, Kutai Timur, Kalimatan Timur. Jurnal Penelitian Hutan Dan Konservasi Alam. 
Https://Doi.Org/10.20886/Jphka.2015.12.2.191-208.

Komariyati, K., Padmarsari, W., \& Surachman, S. (2018). Upaya Penanganan Limbah Olahan Ikan Menjadi Pakan Ternak Unggas Dan Pupuk Organik Cair. Jurnal Pengabdi. Vol. 1(1): 33. Https://Doi.Org/10.26418/Jplp2km.V1i1.25469.

Koroy. (2017). Pengembangan Ekowisata Bahari Berbasis Sumberdaya Pulau- Pulau Kecil Di Pulau Sayafi Dan Liwo, Kabupaten Halmahera Tengah Marine Resource Based Ecotourism Development of Small Islands In Sayafi And Liwo Island, Central Halmahera. Jurnal Teknologi Perikanan Dan Kelautan, Vol. 8 (1):1-17.

Koroy, K., Yulianda, F., \& Butet, N. A. (2017). Pengembangan Ekowisata Bahari Berbasis Sumberdaya Pulau-Pulau Kecil Di Pulau Sayafi Dan Liwo, Kabupaten Halmahera Tengah. Jurnal Teknologi Perikanan Dan Kelautan, Vol. 8 (1): 1-17.

Krisnadianto, A. (2019). Limbah Industri Tempe Rumahtangga Sebagai Pupuk Dan Pakan Ternak Di Kelurahan Pakal Kecamatan Pakal Surabaya. Prosiding Konferensi Nasional Pengabdian Kepada Masyarakat Dan Corporate Social Responsibility (PKM-CSR). Https://Doi.Org/10.37695/Pkmcsr.V2i0.480.

Kristiyanti, M. (2016). Pemberdayaan Masyarakat Pesisir Pantai Melalui Pebdekatan ICZM (Integrated Coastal Zone Management). Seminar Nasional Multi Disiplin Ilmu. Hal. 725-760

Kusumaningrum, D. U., Mahfudz, L. D., \& Sunarti, D. (2018). Pengaruh Penggunaan Tepung Ampas Kecap Pada Pakan Ayam Petelur Tua Terhadap Kualitas Interior Telur Dan Income Over Feed Cost (IOFC). Jurnal Sain Peternakan Indonesia. Jspi. Vol.13.(1): 36-42.

Kusumo, D., Priyanti, A., \& Saptati, R. A. (2017). Prospek Pengembangan Usaha Peternakan Pola Integrasi. Sains Peternakan, 5 (2), 26. Https://Doi.Org/10.20961/Sainspet.V5i2.4924.

Kuswandi. (2011). Teknologi Pemanfaatan Pakan Lokal Untuk Menunjang Peningkatan Produksi Ternak Ruminansia. Pengembangan Inovasi Pertanian. Vol. 4 (3): 189-204.

Laikha, U., Tampubolon, B., \& Subrata, A. (2019). Pengaruh Lama Peram Proses Fermentasi Kulit Kacang Tanah Amoniasi Dengan Aspergillus Niger Terhadap Produksi VFA Dan NH3 Secara In Vitro. Jurnal Ilmu Nutrisi Dan Teknologi Pakan. Vol. 17 (3):69-72.

Lasabuda, R. (2013). Pembangunan Wilayah Pesisir Dan Lautan Dalam Perspektif Negara Kepulauan Republik Indonesia. Jurnal Ilmiah Platax. Jip.1.2.2013.1251.

Latupapua, Y. T. (2007). Studi Potensi Kawasan Dan Pengembangan Ekowisata Di Tual Kabupaten Maluku Tenggara. Jurnal Agroforestri. Vol. 1 (1): 65-71.

Luhur, E. S., Zulham, A., \& Haryadi, J. (2016). Potensi Pemanfaatan Limbah Perikanan Di Banda Aceh. Buletin Ilmiah Marina Sosial Ekonomi Kelautan Dan Perikanan. Https://Doi.Org/10.15578/Marina.V2i1.3276.

Lukiwati DR, Kusmiyati F, Yafizham, Anwar S. 2019. Improvement of plant growth and production of waxy corn with organic-NP enriched manure and inorganic fertilizer in the Sragen District of Central Java Indonesia. International Conference on Food \& Technology. IOP Conf. Series: Earth and Environmental Science 292(2019): 012056. https:// doi.org/10.1088/1755-1315/292/1/012056.

MA Pagala., Munadi, L., Obi,. Zulkarnain. (2019). Bali Cattle Development Strategy Based On The Results Of Palm Oil Plantation In Kolaka District. Ind. J. Anim. Agric. Sci, Vol. 2 (1): 88-97.

MA Pagala., Munadi, L., Obi,. Zulkarnain. (2019). Diversity And Green Types Carrying Capacity Bali Beef In Oil Palm Plantation In Kolaka District. Journal Of Animal Agricultural Science (IJAAS), Vol 1(1):48-55.

Marasabessy, I., Fahrudin, A., Imran, Z., \& Agus, S. B. (2018). Strategi Pengelolaan Berkelanjutan Pesisir Dan Laut Pulau Nusa Manu Dan Nusa Leun Di Kabupaten Maluku Tengah. Journal of Regional And Rural Development Planning, Vol. 2 (1): 11-22.

Marjaya, S. (2016). Analisis Efisiensi Dan Daya Saing Komoditas Pada Sistem Usahatani Integrasi Jagung-Sapi Di Kabupaten Kupang. Ilmu Pertanian (Agricultural Science), 18(3), 164. Https://Doi.Org/10.22146/Ipas.10617.

Marlina, E. T., Zamzam, D. B., \& Hidayati, Y. A. (2019). Pengolahan Terpadu Limbah Ternak Di Kelompok Tani Rancamulya Sumedang. Media Kontak Tani Ternak. Https://Doi.Org/10.24198/Mktt.V1i1.21597

Martin, G., Moraine, M., Ryschawy, J., Magne, M. A., Asai, M., Sarthou, J. P., Duru, M., \& Therond, O. 
(2016). Crop-Livestock Integration Beyond The Farm Level: A Review. Agronomy For Sustainable Development. 36 (3). Https://Doi.Org/10.1007/S13593-016-0390-X

Medi, A., \& Junaidi, A. (2016). Rancang Bangun Mesin Penghancur Borgol Jangung Untuk Campuran Pakan Ternak Sapi Kapasitas Produksi 30kg/Jam. Jurnal PETRA. Vol. 2 (1): 2331

Mirzah, \& Muis, H. (2016). Biokonversi Limbah Kulit Ubi Kayu Menjadi Pakan Unggas Sumber Energi Menggunakan Bacillus Amyloliquefaciens (Bioconverstion Of Cassava Feel Become Poultry Feed Energy Sources Using Bacillus Amyloliquefaciens). Jurnal Ilmu Ternak.Vol.16 (2):59-70

Muhtarom, A. (2017). Analisis Kontribusi Hasil Perikanan Laut Terhadap Kesejahteraan Para Nelayan Dan Masyarakat Di Kabupaten Lamongan. Jurnal Akuntansi. Https://Doi.Org/10.30736/Jpensi.V2i1.91

Munandar, Gustiar F, Yakup, Hayati R, Munawar A.I. 2015. Crop-Cattle Integrated Farming System: An Alternative of Climatic Change Mitigation. Media Peternakan. Journal of Animal Science and Technology. 38 (2). https://doi.org/10.5398/medpet. 2015.38.2.95.

Muliawan, I., Fahrudin, A., Fauzi, A., \& Boer, M. (2016). Analisis Stakeholders Pada Perikanan Tangkap Kerapu, Preliminary Study Menuju Implementasi Ecosystem Approach For Fisheries Management Di Kepulauan Spermonde Kota Makassar. Jurnal Sosial Ekonomi Kelautan Dan Perikanan. Https://Doi.Org/10.15578/Jsekp.V9i2.1224

Muslim, C. (2017). Pengembangan Sistem Integrasi Padi-Ternak Dalam Upaya Pencapaian Swasembada Daging Di Indonesia: Suatu Tinjauan Evaluasi. Pengembangan Sistem Integrasi Padi-Ternak Dalam Upaya Pencapaian Swasembada Daging Di Indonesia: Suatu Tinjauan Evaluasi. 4(3), 227-240. Https://Doi.Org/10.21082/Akp.V4n3.2006.227-240

Nainggolan, H. L., Sihombing, M., Supriana, T., \& Tafsin, M. (2018). Pengaruh Kondisi Internal Pertanian Terhadap Sistem Pertanian Terintegrasi Padi Sawah Dengan Ternak Kerbau Dan Pengembangan Wilayah Di Kabupaten Humbang Hasundutan. Talenta Conference Series: Agricultural And Natural Resources (ANR). Vol. 1 (2):138-149.

Ntelok, Z. R. E. (2017). Limbah Kulit Singkong (Manihot Esculenta L.) : Alternatif Olahan Makanan Sehat. Jurnal Inovasi Pendidikan Dasar. Vol. 1 (1): 115-121.

Nurilmala, M., Nurhayati, T., \& Roskananda, R. (2018). Limbah Industri Filet Ikan Patin Untuk Hidrolisat Protein. Jurnal Pengolahan Hasil Perikanan Indonesia. Https://Doi.Org/10.17844/Jphpi.V21i2.23083.

Pieter, J., Benu, F., \& Kaho, M. R. (2015). Valuasi Ekonomi Ekowisata Terhadap Pengembangan Objek Wisata Kawasan Pesisir. Jurnal Ilmu Lingkungan. Vol. 13 (1):55-64.

Prajanti SDW, Susilowati I. 2016. The Prospect of Integrated Farming System of Crops-fish husbandry as the Survival Strategy to Secure the Farmers' Economy: Case Study in MagelangIndonesia. International Journal of Economics and Financial Issues. 6(S6): 84-87.

Prasiddha, I. J., Laeliocattleya, R. A., \& Estiasih, T. (2016). Potensi Senyawa Bioaktif Rambut Jagung (Zea Mays L) Untuk Tabir Surya Alami: Kajian Pustaka. Jurnal Pangan Dan Agroindustri. Vol. 4 (1): 40-45.

Prasiddha, I. J., Laeliocattleya, R. A., Estiasih, T., \& Maligan, J. M. (2016). The Potency Of Bioactive Compounds From Corn Silk (Zea Mays L.) For The Use As A Natural Sunscreen : A Review. Jurnal Pangan Dan Agroindustri. Vol. 15 (3):175-184.

Pringgenies, D., Yudiati, E., Nuraeni, R. A. T., \& Susilo, E. S. (2017). Pemberdayaan Kelompok Wanita Nelayan Pesisir Pantai Dengan Aplikasi Teknologi Pewarna Alam Limbah Mangrove Jadi Batik Di Mangkang Kecamatan Tugu Semarang. Jurnal Panrita Abdi. Vol. 1 (2): 83-89.

Puastuti, W. 2013. Teknologi pakan untuk mendukung integrasi sapi-sawit. Makalah disampaikan pada Seminar Badan Litbang Pertanian "Inovasi Teknologi Peternakan Mendukung Swasembada Daging 2014 dan Tata Niaga Daging di Indonesia." Jakarta, 19 Februari 2013.

Purnamaningsih, H., Nururrozi, A., \& Indarjulianto, S. (2017). Saponin: Dampak Terhadap Ternak (Ulasan) Saponin : Impact On Livestock (A Review). In Jurnal Peternakan Sriwijaya. Vol. 6(2):79-90.

Rahayu, R. I., Subrata, A., \& Achmadi, J. (2018). Fermentabilitas Ruminal In Vitro Pada Pakan 
Berbasis Jerami Padi Amoniasi Dengan Suplementasi Tepung Bonggol Pisang Dan Molases. Jurnal Peternakan Indonesia (Indonesian Journal of Animal Science). Https://Doi.Org/10.25077/Jpi.20.3.166-174.2018.

Ramdani, D., Abdullah, L., \& Kumalasari, N. R. (2017). Analisis Potensi Hijauan Lokal Pada Sistem Integrasi Sawit Dengan Ternak Ruminansia Di Kecamatan Mandau Kabupaten Bengkalis Provinsi Riau. Buletin Ilmu Makanan Ternak. Vol. 104 (1): 1-8.

Rauf, A., \& Rahmawaty. (2013). Sistem Pertanian Terpadu Di Lahan Pekarangan Mendukung Ketahanan Pangan Berkelanjutan Dan Berwawasan Lingkungan. Jurnal Pertanian Tropik. Https://Doi.Org/10.32734/Jpt.V1i1.2864

Ridlo, M. A., Islam, U., \& Agung, S. (2017). Pengembangan Kawasan Pesisir Pantai Dengan Konsep Agribisnis. Seminar Nasional Perencanaan dan Pembangunan Desa-Kota. Oktober. Hal. 301-308. ISBN : 978-602-73463-1-4

Ruhiyat, R., Indrawati, D., Indrawati, E., \& Siami, L. (2020). Upaya Pemberdayaan Masyarakat Dalam Penerapan Sistem Pertanian Terpadu Di Kampung Injeman, Desa Cibodas, Kecamatan Pasirjambu, Kabupaten Bandung (The Effort Of Community Empowerment In Implementing Integrated Farming System In Injeman Sub-Village, Ci. Vol. 6 (2):97-104.

Rusdiana, S. (2020). Peningkatan Nilai Ekonomi Melalui Difersivikasi Usaha Tanaman Pangan Dan Sapi Bali. Journal Of Economic, Public, And Accounting (JEPA). Https://Doi.Org/10.31605/Jepa.V2i2.662

Sabri, R., Kasmiran, A., \& Fadli, C. (2017). Daya Simpan Wafer Dari Bahan Baku Lokal Sebagai Bahan Pakan Ternak Ruminansia. Jurnal Edukasi dan Sains Biologi. Jesbio. Vol. 6 (1):35-39.

Safitri, L. E., Jumarang, M. I., \& Apriansyah, A. (2016). Studi Potensi Energi Listrik Tenaga Gelombang Laut Sistem Oscillating Water Column (OWC) Di Perairan Pesisir Kalimantan Barat. POSITRON. Https://Doi.Org/10.26418/Positron.V6i1.14536

Salim, H. L., \& Purbani, D. (2015). Pengembangan Pariwisata Bahari Berbasis Masyarakat Di Pulau Kaledupa, Kabupaten Wakatobi, Provinsi Sulawesi Tenggara (Community Based Marine Tourism Development In Kaledupa Island, Wakatobi Regency, South East Sulawesi $\begin{array}{llllll}\text { Province). Jurnal Manusia Dan Lingkungan. Vol. } 22 & \text { (3): } 380 .\end{array}$ Https://Doi.Org/10.22146/Jml.18765

Sambah, A. B., Affandy, D., Luthfi, O. M., \& Efani, A. (2019). Identification And Analysis Of Potential Coastal Areas As Basis For Mapping Conservation Areas In The Coastal District Of Banyuwangi. East Java. Vol. 5: 61-69.

Sari, D. A. A., \& Muslimah, S. (2014). Kebijakan Pengelolaan Pulau-Pulau Kecil Terluar Indonesia Dalam Menghadapi Perubahan Iklim Global. Yustisia, Edisi. 90: 57-73.

Sariubang, M., Qomariyah, N., \& Nurhayu, A. (2013). Sistem Usahatani Terpadu Jagung Dan Sapi Di Kabupaten Takalar Provinsi Sulawesi Selatan. Prosiding Pekan Serealia Nasional, ISBN : 978-979-8940-29-3. Hal. 978-979.

Selvi Tebay, D. C. M. (2017). Pengelolaan Perikanan Tropis. Jurnal Pengelolaan Perikanan Tropis. Vol. 4 (1):19-29.

Setiawan, A., A.K, T. B., \& A.H, Y. (2013). Pengelolaan Limbah Ternak Pada Kawasan Budidaya Ternak Sapi Potong Di Kabupaten Majalengka (Waste Management At Beef Cattle Raising Area In Majalengka). Jurnal Ilmu Ternak. Vol. 13 (1): 24-30

Sihasale, D. A. (2013). Keanekaragaman Hayati Di Kawasan Pantai Kota Ambon Dan Konsekuensi Untuk Pengembangan Pariwisata Pesisir. Journal Of Indonesian Tourism And Development Studies. Vol. 1 (1): 20-27.

Sihite, H. H. (2013). Studi Pemanfaatan Limbah Ikan Dari Tempat Pelelangan Ikan (TPI) Dan Pasar Tradisional Nauli Sibolga Menjadi Tepung Ikan Sebagai Bahan Baku Pakan Ternak. Jurnal Teknologi Kimia Unimal. Vol. 2 (2):43-54

Siswati, L., \& Nizar, R. (2012). Model Pertanian Terpadu Tanaman Hortikultura Dan Ternak Sapi Untuk Meningkatkan Pendapatan Petani. Jurnal Peternakan Indonesia (Indonesian Journal Of Animal Science). Jpi. Vol. 14 (2):379-384.

Solikin, N., Pd, S., Ma, M., Andaruisworo, S., Pt, S., \& Ma, M. (2019). Faktor Faktor Pendukung Keberhasilan Sentra Peternak Rakyat (Spr) Sapi Potong Di Bojonegoro. Universitas Nusantara Pgri Kediri. Skripsi. 2019. 
Sudarman, A., Muttakin, M., \& Nuraini, H. (2014). Penambahan Sabun-Kalsium Dari Minyak Ikan Lemuru Dalam Ransum: 2 Pengaruhnya Terhadap Sifat Kimia Dan Fisik Daging Domba. JITV. Vol. 31 (3): 166-171

Sugandi, D. (2016). Pengelolaan Sumberdaya Pantai. Jurnal Geografi Gea. Vol. 11 (1): 50-58.

Suharyono. (2014). Pengembangan Suplemen Pakan Urea Molases Multi-Nutrien Nutrient Block ( UMMB ) Menggunakan Sumber Protein Tepung Kedelai Dan Gliricidia Sepium (Gs) Untuk Ternak Ruminansia. Jurnal Ilmiah Aplikasi Isotop Dan Radiasi. Vol. 10 (1): 11-22.

Suherman, S., \& Kurniawan, E. (2017). Manajemen Pengelolaan Ternak Kambing Di Desa Batu Mila Sebagai Pendapatan Tambahan Petani Lahan Kering. Jurnal Dedikasi Masyarakat. Https://Doi.Org/10.31850/Jdm.V1i1.246

Sujana, I., Hardiansyah, G., \& Siahaan, S. (2016). Dukungan Teknologi Pada Integrasi Tanaman Hortikultura-Ternak Sapi Untuk Pengembangan Agribisnis Yang Berkelanjutan. Elkha, 8(2), 23-28. Https://Doi.Org/10.26418/Elkha.V8i2.18757

Sujarwo, M. A., Mardiyono, \& Prasetya, W. Y. (2014). Evaluasi Dampak Kebijakan Pembangunan Pelabuhan Perikanan Pantai (PPP) Tamperan Terhadap Perubahan Sosial Ekonomi Masyarakat Pesisir Pantai (Studi Kasus Pada PPP Tamperan Kab. Pacitan). Jurnal Administrasi Publik (JAP). Vol. 2 (11): 1010-1015.

Sun, Z., Guo, Y., Li, C., Cao, C., Yuan, P., Zou, F., Wang, J., Jia, P., \& Wang, J. (2019). Effects Of Straw Returning And Feeding On Greenhouse Gas Emissions From Integrated Rice-Crayfish Farming In Jianghan Plain, China. Environmental Science And Pollution Research. Vol. 26 (12): $11710-11718$.

Suprihatin, M. P., \& Sukardi, T. C. S. (2018). Pengembangan Agroindustri Terpadu Sapi PotongJagung Berkelanjutan: Suatu Tinjauan Literatur. Jurnal APTEK. Http://EJournal.Upp.Ac.Id/Index.Php/Aptk/Article/View/1588

Supriyatna, A., \& Putra, R. E. (2017). Estimasi Pertumbuhan Larva Lalat Black Soldier (Hermetia Illucens) Dan Penggunaan Pakan Jerami Padi Yang Difermentasi Dengan Jamur P. Chrysosporium. Jurnal Biodjati. Https://Doi.Org/10.15575/Biodjati.V2i2.1569

Susanty, S., \& Bachmid, F. (2016). Perbandingan Metode Ekstraksi Maserasi Dan Refluks Terhadap Kadar Fenolik Dari Ekstrak Tongkol Jagung (Zea Mays L.). Jurnal Konversi. Https://Doi.Org/10.24853/Konversi.5.2.87-92

Susilawati, Indriani, N.P, Tanuwiria, \& U.H. (2014). Inovasi Teknologi Pakan Sapi Potong Berbasis Sumberdaya Lokal Di Desa Pasirbungur Dan Purwadadi Barat Kecamatan Purwadadi Kabupaten Subang. Jurnal Aplikasi Ipteks Untuk Masyarakat. Vol. 3 (1):9-12

Tanuwiria, U. H., Yulianti, A., \& Mayasari, N. (2006). Potensi Pakan Asal Limbah Tanaman Pangan Dan Daya Dukungnya Terhadap Populasi Ternak Ruminansia Di Wilayah Sumedang. Jurnal Ilmu Ternak, Vol. 6 (2): 112-120.

Tembo, L., Chabala, L. M., \& Sianangama, P. C. (2020). Assessment Of A Climate-Smart Cropping Combination For Integrated Crop And Livestock Production System. Asian Research Journal Of Agriculture, February. Vol. 12 (2): 8-15.

Tumewu, J. M., Panelewen, V. V. J., \& Mirah, A. D. P. (2014). Analisis Usaha Tani Terpadu Sapi Potong Dan Padi Sawah Kelompok Tani "Keong Mas" Kecamatan Sangkub, Kabupaten Bolaang Mongondow Utara (Studi Kasus). Zootec, Vol. 34 (2): 1. Https://Doi.Org/10.35792/Zot.34.2.2014.5521

Ulfa, M. (2018). Persepsi Masyarakat Nelayan Dalam Menghadapi Perubahan Iklim (Ditinjau Dalam Aspek Sosial Ekonomi. Jurnal Pendidikan Geografi. Https://Doi.Org/10.17977/Um017v23i12018p041

Umboh, S. J. K., Regar, M. N., Lengkong, V., Rembang, H., \& Dalie, S. (2019). Pemberdayaan Kelompok Tani Melalui Aplikasi Teknologi Pakan Berbasis Integrasi Tanaman Ternak. Techno Science Journal. Vol. 1 (1): 8-13.

Wahyudin, Y. (2016). Potensi Bisnis Kelautan Di Negara Maritim Poros Dunia Untuk Kesejahteraan Rakyat Indonesia. In Agrimedia. Vol. 21 (1): 17-22.

Waluyo, A. (2014). Secara Terpadu Yang Berbasis Masyarakat (Studi Kasus Pulau Raas Kabupaten Sumenep Madura). Vol. 7 (2): 75-85.

Wantasen, E., Dalie, S., \& Oroh, F. N. S. (2019). Daya Dukung Hijauan Dan Limbah Tanaman 
Pangan Pengembangan Populasi Ternak Sapi Potong Di Kecamatan Tompaso Kabupaten Minahasa. Pastura. Https://Doi.Org/10.24843/Pastura.2016.V06.I01.P04.

Wardhana, A. H. (2016). Black Soldier Fly (Hermetia Illucens) Sebagai Sumber Protein Alternatif Untuk Pakan Ternak. WARTAZOA: Indonesian Bulletin Of Animal And Veterinary Sciences. Vol. 26 (2): 69-78.

Wardhani, M. K. (2011). Kawasan Konservasi Mangrove: Suatu Potensi Ekowisata. Jurnal Kelautan. Vol. 4 (1): 60-76.

Widarko, A., \& Humaidah, N. (2018). Ibm Peternakan Kambing Yang Memanfaatkan Limbah Pembuatan Tempe Junrejo Batu. JIPEMAS: Jurnal Inovasi Hasil Pengabdian Masyarakat. Https://Doi.Org/10.33474/Jipemas.V1i1.1480.

Widyawati, S. D. (2017). Efek Perbedaan Sumber Protein Dan Rasio Urea-Molases Dalam Pakan Suplemen Yang Ditambahkan Dalam Ransum Terhadap Produksi Mikrobia Rumen Secara In Vitro. Sains Peternakan. Https://Doi.Org/10.20961/Sainspet.V6i1.4942.

Yahya, E., Rosyid, A., \& Suherman, A. (2013). Tingkat Pemanfaatan Fasilitas Dasar Dan Fungsional Dalam Strategi Peningkatan Produksi Di Pelabuhan Perikanan Pantai Tegalsari Kota Tegal Jawa Tengah. Journal Of Fisheries Resources Utilization Management. Vol. 2 (1): 56-65.

Yani, A., \& Sujono. (2014). Produksi Pakan Ikan Dengan Memanfaatkan Limbah Biogas Asal Kotoran Ternak Yang Murah Dan Berkualitas. Dedikasi. Vol. 11 (1): 1-10.

Yuliana, D., Hutabarat, J., Pribadi, R., \& Suprijanto, J. (2013). Konservasi Mangrove Sebagai Pendukung Sumber Hayati Perikanan Pantai. Jurnal Litbang Pertanian. Vol. 23 (1): 15-21.

Yulisa, E. N., Johan, Y., \& Hartono, D. (2016). Analisis Kesesuaian Dan Daya Dukung Ekowisata Pantai Kategori Rekreasi Pantai Laguna Desa Merpas Kabupaten Kaur. Jurnal Enggano. Vol. 1 (1): 97-111.

Yulistiani, D., W. Puastuti, E. W. D. S. (2012). Pengaruh Berbagai Pengolahan Terhadap Nilai Nutrisi Tongkol Jagung : Komposisi Kimia Dan Kecernaan In Vitro. Jitv. Vol. 17 (1): 59-66.

Yusriani, Y., Elviwirda, \& Sabri, M. (2015). Kajian Pemanfaatan Limbah Jerami Sebagai Pakan Ternak Sapi Di Provinsi Aceh. Jurnal Peternakan Indonesia (Indonesian Journal Of Animal Science). Https://Doi.Org/10.25077/Jpi.17.2.163-169.2015

Yusriani, Yenni, \& Susanti, A. E. (2016). Potensi Dan Pemanfaatan Hasil Samping Tanaman Pangan Sebagai Pakan Ternak Ruminansia. Prosiding Seminar Nasional Lahan Suboptimal. Hal. 338-346

Zakaria, A. K. (2016). Kebijakan Pengembangan Budi Daya Kedelai Menuju Swasembada Melalui Partisipasi Petani. Analisis Kebijakan Pertanian. Vol. 8 (3):259-272

Zakiyah, D. M. (2014). Pengembangan Perikanan Budidaya: Efektivitas Program Minapolitan Dalam Pengelolaan Perikanan Budidaya Berkelanjutan Di Kabupaten Gresik. Jurnal Pembangunan Wilayah \& Kota. Https://Doi.Org/10.14710/Pwk.V10i4.8171

Zulaikhah, S. R., Fauziah, F. R., \& Japutra, B. R. (2020). Penyuluhan Pembuatan Amoniasi Jerami Padi Pada Kelompok Tani Terus Jaya Dusun Cunil Desa Pegalongan Kecamatan Patikraja. Cendekia : Jurnal Pengabdian Masyarakat. Vol. 2 (1): 33-38. 